\title{
Justice, Janus-like: The future of Australian personal injury compensation
}

\author{
ELEANOR WALLIS
}

\section{Abstract}

'Justice, Janus-like' is a comparative assessment of the ability of the negligence system and the pure no-fault system to provide ethical, fair and adequate compensation to victims of personal accident in Australia. This paper arose from a concern that neither of these schemes fully satisfies the needs of victims and society. The comparative assessment focuses on three key goals of personal injury compensation schemes: adequate and quick compensation, deterrence potential, and the ability to achieve social justice. By evaluating the tort of negligence and a pure no-fault compensation scheme against these criteria, this essay found each system is fundamentally flawed. As such, this paper proposes that the fairest, most effective and socially useful mechanism to compensate victims of personal injury is through the implementation of a hybrid system: the tort of public liability. This alternative is capable of achieving all the key goals of personal injury compensation, while at the same time avoiding the challenges faced by both the negligence and no-fault systems. Australia is quickly moving into the future of personal injury compensation, with more jurisdictions considering the implementation of full no-fault schemes. This paper demonstrates that this approach is imperfect and, as such, an alternative scheme, such as the public liability tort, must be considered. As we move into the future, we must seriously consider the shortcomings of our current legal system, and find a way of compensating victims that achieves all three aims of compensation: deterrence, ethical justice and fair compensation.

1 Michael Kirby, 'Tort System Reforms: Causes, Options, Outcomes' (2001) 8 Journal of Law and Medicine 380,38 . 


\section{Introduction}

There are over 20000 people with a 'catastrophic-level' injury in Australia, with up to a thousand being injured each year. ${ }^{2}$

Providing adequate and just compensation, deterring tortious conduct and satisfying ethical justice are three key aims of modern tort law in relation to personal injury. ${ }^{3}$ This essay will assess the performance of the common law of negligence in each of these three areas, evaluating it against a pure no-fault scheme. It will be shown that the operation of modern tort law, particularly after the 2002 reforms, struggles to achieve these three goals effectively. However, no-fault schemes similarly do not achieve perfect results. As such, the results of this dual-faced, 'Janus-like' investigation will reveal that neither tort law nor no-fault schemes alone should have a place in the future for personal injury compensation in Australia. ${ }^{4}$ Instead, this essay will offer that the most effective route for personal injury compensation is a 'Janus-like' combination of the advantages of both schemes into an alternative system of compensation.

\section{The basic principles of negligence and no-fault compensation}

It is wise to begin with brief definitions of both common law compensation and no-fault compensation. Common law compensation is the compensation pursued through the courts in the action of negligence; negligence being widely accepted as the construction found in the hallmark case of Donoghue v Stevenson. ${ }^{5}$ Liability will be established when the plaintiff demonstrates that:

a. the defendant owed the plaintiff a duty of care;

b. this duty of care was breached by the defendant; and,

c. the injury/damage of the plaintiff was as a result of this breach. ${ }^{6}$

No-fault refers to 'pure' systems of no-fault compensation, such as New Zealand's Accident Compensation Act. ${ }^{7}$ Such schemes allow injured parties to pursue compensation from government-funded sources and do not require the claimant to prove fault — only that the injury was caused by accident. ${ }^{8}$ In exchange for receiving

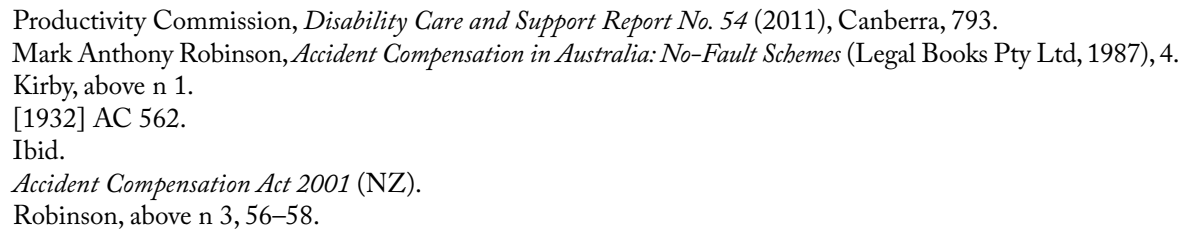


compensation, the right to sue in negligence is generally relinquished. ${ }^{9}$ Australia has various no-fault schemes, but these currently act only as 'add-ons' that provide limited no-fault benefits. ${ }^{10}$ This essay considers the concept of no-fault schemes where they are the only means to seek compensation, rather than in the 'add-on' nature they take in the Australian jurisdiction. This was done to gain clarity and uniformity in analysis of the abilities and limitations of no-fault schemes.

\section{Ethical justice}

Personal injury compensation is inextricably linked with notions of ethics: the ideal of achieving moral justice for victims of injury. ${ }^{11}$ Firstly, compensation should provide a means for the victim to feel that the one responsible for their loss has been held accountable. ${ }^{12}$ Secondly, it should be able to provide assistance to all those hurt, whether through the fault of another or the hand of fate, as we have a collective social responsibility to ensure the care of injured members of society. ${ }^{13}$ The ability of tort law and no-fault schemes to achieve both of these key aims will be considered.

\section{Creating meaning through litigation}

Tort law allows injured plaintiffs to personally pursue the one that wronged them. ${ }^{14}$ In this sense, tort law is inherently valuable due to its ability to provide 'social justice' to plaintiffs, giving them a sense of meaning. ${ }^{15}$ An empirical study of 227 plaintiffs demonstrated that the cases were brought in tort to gain explanations for the injury, seek self-justification, satisfy desires for vindication, and to force the defendant to accept responsibility for their actions. ${ }^{16}$ If tort law provides such social justice to plaintiffs, it is a valuable moral tool for our society. However, the practical realities of the legal system mean that such desires may often remain unfulfilled. The operation of confidentiality, the fact that the personal defendant may not appear in court but rather their insurance company, the low public profile of negligence cases and the high frequency of settlement (around 90 per cent settling before trial) are factors that undermine the ability of tort law to realise the

9 Talina Drabsch, 'No Fault Compensation' (Briefing Paper No. 6/05, NSW Parliamentary Library, Parliament of NSW, 2005), 53.

10 See e.g. National Disability Insurance Scheme Act 2013 (Cth), Sporting Injuries Insurance Act 1978 (NSW) and various motor accident compensation schemes such as Motor Accidents Compensation Act 1999 (NSW).

11 Emmanuel Voyiakis, 'Rights, Social Justice and Responsibility in the Law of Tort' (2012) 35 UNSW Law Journal 449, 449-50.

12 Hassan El Menyawi, 'Public tort liability: recommending an alternative to tort liability and no-fault compensation' (2003) 3 Global Jurist Advances, 2.

13 Izhak Englard, The Philosophy of Tort Law (Dartmouth Publishing, 1993), 110.

14 Perre v Apand (1999) 164 ALR 606, McHugh J at [103].

15 Ibid; Menyawi, above n 12, 3.

16 Charles Vincent, Magi Young and Angela Phillips 'Why do people sue doctors? A study of patients and relatives taking legal action' (1994) 343, 8913 The Lancet 1609. 
moral needs of plaintiffs. ${ }^{17}$ It must be asked whether it is the actual attainment or merely the pursuit of such aims that creates moral meaning for plaintiffs. This is an interesting question on which there is little empirical evidence to demonstrate either way. However, it is not far-fetched to claim that the moral value of tort law is reduced by its practical operation: if the aims of the plaintiff are not realised, this necessarily undermines the ability of tort law to grant social justice.

However, no-fault schemes without doubt fail in creating meaning for injured plaintiffs by completely removing the possibility to seek accountability from the defendant. ${ }^{18}$ The very nature of no-fault schemes means that the defendant is not the one who pays for the damage they have caused, but rather society through the proxy of the state. ${ }^{19}$ In this way, from the plaintiff's perspective, the defendant escapes without having to bear the responsibility for the harm and suffering they have caused, and the vengeance sought by the plaintiff will never be obtained. ${ }^{20}$ The operation of such schemes in this way results in the removal of the right to pursue one who has injured you, and raises the possibility of 'heightening the emotional distress' of the plaintiff, who views a lack of accountability as an essential failure of justice. ${ }^{21}$

Both no-fault and tort law cannot completely achieve moral aims of seeking retribution and accountability. An alternate system is needed to advance social justice in the future of personal injury compensation.

\section{No fault, no damages}

The law of negligence fails to compensate innocent victims of accident. ${ }^{22}$ We as a society have an undeniable moral responsibility to the innocently injured. ${ }^{23}$ This cannot be achieved through the law of negligence- a system that operates by finding and assigning fault to a defendant. If fault cannot be found, the claimant will receive no compensation, a seemingly unfair result. ${ }^{24}$ For example, in the common law, it is entirely possible a plaintiff who is 80 per cent responsible for their own injury to receive compensation whereas an innocent victim who can find nobody at fault receives nothing. ${ }^{25}$ This seems morally unfair; to gain moral justice in our society, we must be able to compensate injury without fault. This is obviously a key operation of no-fault systems. The very nature of no-fault systems

17 Carl Baar, 'The Myth of Settlement' (Speech delivered at the Annual Meeting of the Law and Society Association, Chicago, 28 May 1999).

18 Englard, above n 13, 114.

19 Robinson, above n 3, 56.

20 Englard, above n 13, 114.

21 Menyawi, above n 12, 3-5.

22 Peter Cane and Patrick Atiyah, Atiyah's Accidents, Compensation and the Law (Butterworths, 6th ed, 1999), 140-3.

23 Englard, above n 13, 110.

24 Clothier, Cecil, 'Medical Negligence and No-Fault Liability' (1989) 333 The Lancet 603, 604.

25 Cane and Atiyah, above n 22, 153. 
is that injury and accident can be easily compensated without consideration of fault. ${ }^{26}$ The failure of the law of negligence to enable this key moral goal sheds doubt on whether negligence should be used as the only means for compensating personal injury.

\section{Compensation}

Compensation of injury victims is a major aim of both tort law and no-fault schemes. To evaluate the performance of both schemes, this section will consider their effectiveness at providing timely, just and adequate compensation. To gain a fuller picture, the law of negligence in theory as well as in practice after the 2002 reforms will be evaluated.

\section{Tort law and compensation}

Numerous legal academics condemn tort law as nothing more than an expensive and inefficient 'lottery' that provides arbitrary and unfair compensation. ${ }^{27}$ The 'lottery' of compensation is determined by the adversarial nature of the Australian legal system, which means that similar victims obtain dissimilar results. This may result from minute changes in evidence, varying skills of lawyers, and the prevailing attitudes of the court. ${ }^{28} \mathrm{~A}$ disadvantage of tort systems is that tort litigation is lengthy and means plaintiffs may remain uncompensated for long periods of time. The average negligence case will take around 12 to 18 months, whereas more difficult cases may take up to 10 years. ${ }^{29}$ Finally, tort law compensates for non-pecuniary loss. ${ }^{30}$ The ability of tort law to do so is a major advantage of the system, as common morality provides that one should be compensated for pain and suffering. However, the compensation for such losses adds to the arbitrary nature of tort law, as this type of compensation 'is one which, from its very nature, is incapable of being performed with accuracy'. ${ }^{31}$

\section{Impact of the 2002 reforms}

Substantial law reforms throughout the last decade have altered the traditional operation of Australian negligence law and we must consider the ability of reformed tort law to compensate personal injury. Considerable reform after the release of the Ipp Report in 2002 attempted to restrict the operation of the

\footnotetext{
26 Menyawi, above n 12, 6.

27 Patrick Atiyah, The Damages Lottery (Hart Publishing, Oxford, 1997), 143.

28 Cane and Atiyah, above n 22, 147.

29 CMC Laywers, Compensation Claims (2014) CMC Lawyers, www.cmclawyers.com.au/nsw/compensationlawyer-services; Atiyah, above n 27, 148 .

30 Cane and Atiyah, above n 22, 162; Barker, Kit et al., The Law of Torts in Australia (Oxford University Press, 5th ed, 2012), 715 .

31 Todorovic v Waller (1981) 150 CLR 402, Stephen J at [5].
} 
doctrine, amongst other things substantially limiting the award and amount of damages. ${ }^{32}$ For example, in NSW damages for non-economic losses are capped at $\$ 350,000$, the court can no longer award punitive damages, and damages will not be awarded unless there is whole person impairment of at least 15 per cent. ${ }^{33}$ The impact of such reforms has been to exclude vast numbers of plaintiffs as well as reduce the damages awarded by the court. The reforms have lessened the ability of the common law to compensate justly and effectively, creating systems 'in which fair compensation has given way to financial and political concerns'. ${ }^{34}$

Overall, while tort law compensates personal injury generously, the arbitrary, lengthy and newly restricted nature of the system post-2002 renders it an unsatisfactory system for the future of personal injury compensation.

\section{No-fault schemes}

No-fault systems rectify many faults of tort law compensation. They provide consistent amounts of damages for similar cases: an egalitarian system of compensation. ${ }^{35}$ Compensation under a no-fault scheme is timely, allowing the injured plaintiff to get the funds they need within weeks to months. ${ }^{36} \mathrm{No}$-fault systems provide one significant benefit when compared with negligence law-they are much less costly due to reduced administrative costs. In tort litigation around only 10-15 per cent of the costs of litigation go towards victim compensation. ${ }^{37}$ However, in no-fault systems, much more of the funds within the scheme can be channelled back to compensating claimants-it costs around seven cents for the New Zealand Accident Compensation Corporation to deliver one dollar in benefit. ${ }^{38}$

However, the most significant disadvantage to no-fault schemes is their tendency to undercompensate victims. The state is only capable of compensating to a certain amount whereas the court can theoretically award common law damages as high as the defendant's net wealth. ${ }^{39}$ Under the New Zealand scheme, damages are not awarded for non-pecuniary loss or for loss of future earning capacities, and weekly damages are calculated at up to 80 per cent of the claimant's pre-injury wage. ${ }^{40}$

\footnotetext{
32 Ipp et al., Review of the Law of Negligence: Final Report (Commonwealth of Australia, 2002).

33 Civil Liability Act 2002 (NSW) s 16(2), s 21, s 26C.

34 Law Society of NSW, Submission to the Legislative Council General Purpose Standing Committee No. 1

Inquiry into Personal Injury Compensation Legislation, March 2005, 19.

35 Menyawi, above n 12, 6; Cane and Atiyah, above n 23, 150-3.

36 Accident Compensation Act 2001 (NZ) s 54.

37 Stephen Sugarman, 'Doing away with Tort Law' (1985) 73 California Law Review 555, 558-9.

38 Drabsch, above n 9, 40.

39 Menyawi, above n 12, 7.

40 Accident Compensation Act 2001 (NZ) s 69(1).
} 
This raises concerns about the future of seriously injured claimants - they may not be able to 'live independently' as they would under an award of common law damages. ${ }^{41}$

On the whole, it is arguable that no-fault systems provide more effective compensation for personal injury than tort law, especially considering the restricted operation of tort law after the 2002 reforms. However, the under-compensation of victims in no-fault schemes is a seriously concerning problem. This analysis demonstrates that no-fault schemes or common law negligence alone are not the most satisfactory method for compensation of personal injury, but rather that an alternative scheme should be considered.

\section{Deterrence}

Deterrence is a key rationale for the existence of tort law. ${ }^{42}$ If tort law effectively deters dangerous conduct, this is substantial justification for a continued role in the future of personal injury compensation. ${ }^{43}$

\section{Does tort law deter?}

The theory behind the deterrent effect of tort law is that the threat of financial sanction in the form of litigation and damages will ensure people take adequate care not to injure others through negligent conduct. ${ }^{44}$ However, this traditional justification is being called into doubt: a recent 2011 study of 700 individuals revealed systemic failures in the ability of tort law to deter. ${ }^{45}$ The study found tort liability had insignificant impact on the prevention of tortious behaviour. ${ }^{46}$ This could be due to a number of factors.

Firstly, the effectiveness of tort law as a deterrent is largely undermined by the presence of comprehensive liability insurance. ${ }^{47}$ Such insurance shifts the financial burden from the defendant to the insurance company, virtually eliminating personal accountability. Liability insurance does indeed 'deaden the deterrent role of tort law' ${ }^{48}$ Secondly, tort law cannot possibly deter inadvertent negligence-

41 Drabsch, above n 9, 3.

42 Robinson, above n 3, 4.

43 Mark Harrison, 'Evidence-free Policy: The Case of the National Injury Insurance Scheme' (2013) 20 Agenda 95; Gary T Schwartz,'Reality in Economic Analysis of Tort Law: Does Tort Really Deter?' (1997) 42 UCLA Law Review $377,378$.

44 Jonathon W. Cardi, Randy Penfield and Albert H. Yoon, 'Does Tort Law Deter?' (2011) Legal Studies Paper

No. 1851383, Wake Forest University, North Carolina, 2; Schwartz, above n 43, 560.

45 Cardi, above n 44.

46 Ibid, above n 44, 24-25.

47 National Committee of Inquiry, Compensation and Rehabilitation in Australia (Chairperson: O. Woodhouse), July 1974, 40.

48 Robinson, above n 3, 48. 
the lapses of concentration that cause tortious conduct. ${ }^{49}$ Although logically sound to place liability on this type of conduct, it is arguable whether tort law has any impact in its deterrence. People acting inadvertently are not using their rational minds (which would otherwise be aware to the threat of sanctions or liability) in that moment, and it follows that threat of litigation cannot serve to discourage future inadvertent conduct. ${ }^{50}$ Finally, the uncertainty of tort litigation destabilises its deterrence effect. ${ }^{51}$ The more certain the chance of encountering a sanction, the greater the deterrent effect of the sanction. ${ }^{52}$ Due to the uncertain nature of common law litigation-for example, doubts over whether an action will be brought in the first place, what the court will find and whether they will impose damages - the prospect of being sued in tort is far from the minds of the general population. This further weakens the deterrent effect of tort.

\section{Do no-fault systems deter?}

Tort law's weak deterrent effect still remains superior to that encountered in a no-fault scheme. No-fault compensation inherently fails to provide any measure of deterrence because links between risky actions and costs of these actions are severed..$^{53} \mathrm{~A}$ defendant can engage in tortious conduct with confidence that any financial penalty will not fall upon them but rather on the state due to the operation of a no-fault system. A dangerous consequence of removing this notion of accountability is the possibility of increased injury rates. ${ }^{54}$ Indeed, empirical evidence demonstrates a clear correlation between the introduction of pure no-fault schemes and increases in injuries and fatalities. Motor vehicle accident fatalities in the Northern Territory and New Zealand rose from 16 to 20 per cent after these jurisdictions adopted pure no-fault schemes. ${ }^{55}$ Such evidence illuminates that a 'no fault scheme does not provide the necessary incentives to deter wrongful conduct'. 56

In this regard, it is clear that while neither system provides perfect deterrence, tort law is better equipped to deter tortious conduct than no-fault schemes. However, an alternative scheme for compensation that increases deterrent effect of tort should be considered.

\footnotetext{
49 Cane and Atiyah, above n 22, 147.

50 Ibid.

51 Cardi, above n 44, 23.

52 Ibid, 25.

53 Bronwyn Howell, Judy Kavanagh and Lisa Marriott, 'No-fault public liability insurance: Evidence from New Zealand', (2002) 9 Agenda, 137, 137.

54 Harrison, above $\mathrm{n} 43$.

55 P. Swan, 'The Economics of Law: Economic Imperialism in Negligence Law, No Fault Insurance, Occupational Licensing and Criminology?' (1984) 92 Australian Economic Review 108, 110.

56 Menyawi, above n 12, 10.
} 


\section{The future of personal injury compensation}

The evaluation of tort has demonstrated considerable failures in the way this system operates to compensate for personal injury. However, the introduction of no-fault schemes, which have their own inherent disadvantages, cannot be a panacea to the insufficiencies of the law of negligence. The best way to move into the future of personal injury compensation is a scheme that combines the advantages and avoids the disadvantages of both negligence and no-fault systems.

\section{Janus-like justice: The best of both worlds}

Menayawi posited the idea of 'public tort liability' as the best alternative to compensating victims of personal injury. ${ }^{57} \mathrm{It}$ is based on the idea that 'the state ought to compensate all victims of injury regardless of whether they committed a fault, but also pursue those who committed a wrong in order to hold them accountable'. ${ }^{58}$ In this scheme, the state provides compensation to any injured victim, and then separately conducts investigation of fault-based injury. ${ }^{59}$ If fault is found, the negligent party is ordered to pay damages back to the state, these damages fund the operation of the scheme. ${ }^{60} \mathrm{I}$ believe that such an alternative should be seriously considered as we move into the future of personal injury compensation.

\section{Compensation}

This alternative scheme would avoid many of the disadvantages of both tort and nofault systems in their abilities to compensate for personal injury. As the state is free to compensate first and investigate later, instant compensation could be provided. ${ }^{61}$ As the scheme would be funded by damages paid by defendants as well as being supplemented by taxation, the state would be financially capable of compensating more generously than pure no-fault schemes. ${ }^{62}$ Clearly, such an alternative offers practical benefits and a more satisfactory approach to compensation than either tort or no-fault schemes. Compensation would be fast, adequate and fair.

\section{Deterrence}

The primary criticism of no-fault schemes-the removal of accountability and deterrence-would be avoided in this alternative scheme. As the state pursues the defendant and requires them to take responsibility for their fault by paying damages for the harm they caused, the scheme maintains notions of blame, accountability

57 Menyawi, above $\mathrm{n} 12$.

58 Ibid, 10.

59 Ibid.

60 Ibid, 11.

61 Ibid.

62 Ibid. 
and ensures the (albeit weak) deterrent effect of common law negligence is not lost. ${ }^{63}$ Indeed, that the state rather than the individual pursues the negligent party adds to the deterrent effect of this system: the almost criminal-like aspect of being pursued by the state is more certain than being pursued by an individual in tort, and would arguably lend weight to increased deterrence. ${ }^{64}$

Ethical Justice

This alternative scheme satisfies ethical justice more effectively than either tort or no-fault regimes. Compensation can be provided to those who are injured by accidents, satisfying the community's moral responsibility to protect and compensate injured members of society, and overcome a major flaw of tort law. ${ }^{65}$ Importantly, this scheme would allow victims to seek meaning and achieve a sense of self-justice, as the defendant is still being pursued and held accountable for their wrongs, surpassing the primary moral flaw of no-fault schemes.

\section{Conclusion}

A dual-natured evaluation of tort and no-fault schemes has revealed that both contain inherent inadequacies in their abilities to provide effective compensation, deterrence and social justice for personal injury. The fundamental flaws inherent in both schemes calls for the introduction of alternative systems of compensation that can achieve these three aims effectively, avoiding the downfalls of both the tort and no-fault systems. The Janus-like scheme proposed in this essay is one possibility of such an alternative, and should be considered carefully as we move into the future of personal injury compensation.

\section{Bibliography}

\section{Articles}

Brahams, Diana, “No-Fault” Compensation: Reform of Present System Long Overdue' (1985) 325 The Lancet 1403.

Carver, Tracey, 'Insurance and the law of negligence: An influential or irrelevant persuader?’ (2011) 22 Insurance Law Journal 51.

Clothier, Cecil, 'Medical Negligence and No-Fault Liability'(1989) 333 The Lancet 603.

63 Ibid, 12.

64 Cardi, above n 44.

65 Englard, above n 13, 114. 
Drabsch, Talina, 'Accident compensation: personal responsibility or community responsibility?' (2005) 2 Australian Civil Liability 67.

El Menyawi, Hassan, 'Public tort liability: Recommending an alternative to tort liability and no-fault compensation' (2003) 3 Global Jurist Advances.

Fleming, John G., 'Is there a future for Tort?' (1983-1984) 44 Louisiana Law Review 1193.

Gilead, Israel, 'Tort Law and Internalisation: The Gap Between Private Loss and Social Cost' (1997) 17 International Review of Law and Economics 589.

Harrison, Mark, 'Evidence-free Policy: The Case of the National Injury Insurance Scheme' (2013) 20 Agenda 95.

Howell, Bronwyn, Judy Kavanagh and Lisa Marriott, 'No-fault public liability insurance: Evidence from New Zealand', (2002) 9 Agenda 137.

Ipp, Justice David, 'Negligence - Where lies the future?' (2003) 23 Australian Bar Review 158.

Keeler, John, 'Personal responsibility and the reforms recommended by the Ipp Report: "Time future contained in time past" (2006) 15 Torts Law Journal 48.

Kessler, Daniel P., Nicholas Summerton and John R. Graham 'Effects of the medical liability system in Australia, the UK, and the USA' (2006) 368 The Lancet 240.

King, Stephen P., 'Does Tort Law Reform Help or Hurt Consumers?' (2010) 86 The Economic Record 564.

Kirby, Michael, 'Tort System Reforms: Causes, Options, Outcomes' (2001) 8 Journal of Law and Medicine 380.

Landes, Elisabeth M., 'Compensation for Automobile Accident Injuries: Is the Tort System Fair?' (1982) 11 The Journal of Legal Studies 253.

Mason, Justice Keith, 'Fault, Causation and Responsibility: Is tort law just an instrument of corrective justice?' (2000) 19 Australian Bar Review 201.

McNamara, Michael J. and Nancy H. Kratzke, 'Workers Compensation v Tort Liability' (1997) 50 Chartered Property and Casualty Underwriters Journal 246.

O'Connell, Jeffrey, 'Tort Versus No-Fault: Compensation and Injury Prevention' (1987) 19 Accident Analysis and Prevention 63.

Schwartz, Gary T., 'Reality in Economic Analysis of Tort Law: Does Tort Really Deter?' (1997) 42 UCLA Law Review 377. 
Smillie, John, 'The Future of Negligence' (2007) 15 Torts Law Journal 300.

Spigelman, J.J., 'Negligence: the Last Outpost of the Welfare State' (2002) 776 The Australian Law Journal 432.

Spigelman,J.J.,'Negligence and insurance premiums: Recent changes in Australian Law' (2003) 11 Torts Law Journal 1.

Spigelman, J.J., 'Tort law reform: An overview'(2006) 14 Tort Law Review 5.

Sugarman, Stephen, 'Doing away with Tort Law' (1985) 73 California Law Review 555.

Swan, P., 'The Economics of Law: Economic Imperialism in Negligence Law, No Fault Insurance, Occupational Licensing and Criminology?' (1984) 92 Australian Economic Review 108.

Tancredi, Laurence R., 'Designing a No-Fault Alternative' (1986) 49 Law and Contemporary Problems 277.

Vincent, Charles, Magi Young and Angela Phillips 'Why do people sue doctors? A study of patients and relatives taking legal action' (1994) 343, 8913 The Lancet 1609.

Voyiakis, Emmanuel, 'Rights, Social Justice and Responsibility in the Law of Tort' (2012) 35 UNSW Law Journal 449.

Weisbrot, David and Kerry J. Breen, 'A no-fault compensation system for medical injury is long overdue' (2012) 195 Medical Journal of Australia 296.

Williams, Greg, 'In whose interest? Identifying the issues in proportionate liability litigation' (2006) 3 Australian Civil Liability 25.

Wright, E.W., 'National trends in personal injury litigation: Before and after "Ipp" (2006) 14 Torts Law Journal 233.

\section{Books and book chapters}

Atiyah, Patrick, The Damages Lottery (Hart Publishing, Oxford, 1997).

Barker, Kit, Peter Cane, Mark Lunney and Francis Trindade, The Law of Torts in Australia (Oxford University Press, 5th ed, 2012).

Cane, Peter, The Political Economy of Personal Injury Law (University of Queensland Press, 2007).

Cane, Peter and Patrick Atiyah, Atiyah's Accidents, Compensation and the Law (Butterworths, 6th ed, 1999). 
Englard, Izhak, The Philosophy of Tort Law (Dartmouth Publishing, 1993).

O'Connell,Jeffery and C. Brian Kelly, The Blame Game (D.C Heath and Company, 1987).

Robinson, Mark Anthony, Accident Compensation in Australia: No-Fault Schemes (Legal Books Pty Ltd, 1987).

\section{Cases}

Donoghue v Stevenson [1932] AC 562.

Perre v Apand (1999) 164 ALR 606.

Todorovic v Waller (1981) 150 CLR 402.

\section{Legislation}

Accident Compensation Act 2001 (NZ).

Civil Liability Act 2002 (NSW).

Motor Accidents Compensation Act 1999 (NSW).

National Disability Insurance Scheme Act 2013 (Cth).

Sporting Injuries Insurance Act 1978 (NSW).

\section{Other}

Baar, Carl, 'The Myth of Settlement' (Speech delivered at the Annual Meeting of the Law and Society Association, Chicago, 28 May 1999).

Cardi, Jonathon W., Randy Penfield and Albert H. Yoon, 'Does Tort Law Deter?' (2011) Legal Studies Paper No. 1851383, Wake Forest University, North Carolina.

CMC Laywers, Compensation Claims (2014) CMC Lawyers, www.cmclawyers. com.au/nsw/compensation-lawyer-services.

Doepel, Mark and Chad Downie, 'A Comprehensive Guide to Tort Law Reform throughout Australia' (2006) Kennedys Legal Advice, accessible at, www.kennedys-law.com/files/Uploads/Documents/AusGuidetoTortLaw_ November2006.pdf.

Drabsch, Talina, 'No Fault Compensation' (Briefing Paper No. 6/05, NSW Parliamentary Library, Parliament of NSW, 2005). 
Ipp, David, Peter Cane, Don Sheldon and Ian Macintosh, Review of the Law of Negligence: Final Report (Commonwealth of Australia, 2002).

Law Society of NSW, Submission to the Legislative Council General Purpose Standing Committee No. 1 Inquiry into Personal Injury Compensation Legislation, March 2005, 19.

National Committee of Inquiry, Compensation and Rehabilitation in Australia (Chairperson: O. Woodhouse), July 1974.

North, John, 'Tort Law: What's the Point?' (Speech delivered at the Inaugural ACT Branch Conference of the Australian Lawyers Alliance, Canberra, 24 June 2005).

Productivity Commission, Disability Care and Support Report No. 54 (2011), Canberra. 
This text is taken from The ANU Undergraduate Research Journal, Volume Seven, 2015, edited by Daniel McKay, published 2016 by ANU eView, The Australian National University, Canberra, Australia. 